\title{
KSIAZŻKA POLITYCZNO-PRAWNA W RĘKACH SIEDEMNASTOWIECZNEJ SZLACHTY KORONNEJ
}

Przedmiotem niniejszego szkicu - nawiązującego do pracy magisterskiej „Rola i funkcje książki polityczno-prawnej w środowisku szlachty koronnej w XVII w." ${ }^{1}-$ są rozważania nad wybranymi elementami recepcji ksiażki polityczno-prawnej w siedemnastowiecznej Polsce.

Zakres chronologiczny wspomnianej pracy wyznaczają daty 1587-1732, przyjęte jako umowne granice epoki Baroku w Polsce ${ }^{2}$, zasięg terytorialny - granice Korony.

Praca stanowiła próbę określenia stosunku poszczególnych warstw i całości stanu szlacheckiego do literatury polityczno-prawnej.

Jako metodę badawczą zastosowano analizę porównawczą struktury ilościowo-tematycznej opublikowanych inwentarzy księgozbiorów szlacheckich, istniejących na terenie Korony w latach $1587-1732^{3}$ i repertuaru wydawniczego krajowych oficyn drukarskich z zakresu literatury polityczno-prawnej opublikowanej w latach 1501-1732 (badania bibliograficzne) ${ }^{4}$.

Taki sposób postępowania wynikał z założenia, że $z$ analizą inwentarzy księgozbiorów prywatnych - ważnego źródła do badań czytelnictwa pojmowanego jako proces recepcji piśmiennictwa przez kręgi publiczności czytelniczej - ściśle wiąze się problem rekonstrukcji oferty wydawniczej, jako jednego z głównych czynników wpływających na dostępny w danym czasie i miejscu zasób piśmiennictwa ${ }^{5}$.

Dane dotyczące repertuaru uydawniczego oraz zespół inwentarzy księgozbiorów prywatnych traktowane jako źródła masowe pozwalają na preprowadzenie badań kwantytatywnych, dzięki którym można określić stopień i rodzaj zależności zachodzących między ofertą oficyn drukarskich a strukturą ilościowo-tematyczną księgozbiorów.

Z kolei analiza statystyczna i treściowa wymienionych źródeł pozwala na podjęcie próby określenia kanonów lekturowych charakterystycznych dla danej epoki oraz preferencji grupowych i indywidualnych czytelników.

Określone w ten sposób: przedmiot i metoda badań nasuwają pewne, ogólne refleksje na temat definicji staropolskiej książki polityczno-prawnej i jej funkcji spolecznej.

Ustrój polityczny Rzeczypospolitej Obojga Narodów miał charakter swoistej monarchii parlamentarnej, jednak ze względu na skład społeczny warstwy rządzącej zwykło się go określać mianem demokracji szlacheckiej. Organizacja państwa opierała się teoretycznie na zasadach równości prawnej stanu szlacheckiego, 
nietykalności osobistej i majątkowej, wolności druku i słowa, wolności nauki i nauczania ${ }^{6}$ (przynajmniej w XVI wieku).

Przywileje, jakie wywalczył sobie stan szlachecki w ciaggu XV i XVI w., zapewniły szlachcie całość praw politycznych, możliwość p ow s z e c h n e g o udziału w sprawowaniu władzy, rozstrzygania o urządzeniach ustrojowych, polityce zagranicznej, wewnętrznej, gospodarczej i społecznej państwa.

Oczywiście kształt państwa ulegał w ciągu XVII wieku zmianom. W Rzeczypospolitej rozwijają się rądy tzw. oligarchii magnackiej, w której nadrzędną rolę w życiu społeczno-politycznym kraju odgrywają możnowładcy. Następuje proces decentralizacji rządów polegający na ograniczeniu zwierzchniej władzy monarchy ${ }^{7}$ i wzroście znaczenia sejmików prejmujących stopniowo kompetencje niesprawnego sejmu walnego - „od trzeciej ćwierci XVII wieku możemy już mówić o rąadach sejmikowych w Polsce",

Model ustrojowy zmuszał więc szlachtę do uczestniczenia w życiu społecznopolitycznym państwa (jeśli nie w czynnej, to chociaż biernej formie, np. w ramach tzw. opinii publicznej). Wszelkie formy aktywności politycznej uwarunkowane były (i sa) posiadaniem przynajmniej minimalnego zasobu informacji z tego zakresu. Stąd kulturę polityczną szlachty cechował dobrze rozwinięty system informacyjnopropagandowy, który sprawił, że „zorientowanie się szlachty w sprawach państwowych było większe, niż w innych krajach rądzonych absolutnie"9.

Można wymienić następujące elementy tego systemu ${ }^{10}$ :

- słowo (mówione i pisane): słowo mówione odgrywało ogromną rolę w kulturze politycznej okresu staropolskiego. Jego przewaga nad innymi środkami przekazu (np. drukiem) wynikała z retorycznego charakteru kultury dawnej Polski i ze stopnia alfabetyzacji stanu szlacheckiego ${ }^{11}$.

- obraz: formy plastyki, architektury trwałej i okazjonalnej. Należy tutaj podkreślić polityczne wątki książki ikonograficznej, wykorzystywanej często jako narzędzie oddziaływania propagandowego.

- słowo i obraz: np. kompozycje emblamatyczne

- widowiska: teatralne, operowe i religijne.

W ramach powyższego schematu funkcjonowała także książka polityczno-prawna. Pojęcie książki tego typu nie jest do końca zdefiniowane. Na przykład według J. Czubka istotą literatury politycznej jest jej jednoznacznie agitacyjny, perswazyjno-propagandowy charakter. W tym kontekście wymienia on wylącznie utwory $i$ pisma ulotne, obliczone na masowego odbiorcę, informujące opinię szlachecką o określonych wydarzeniach i zarazem propagujące programy polityczne pewnych frakcji, koterii szlacheckich ${ }^{12}$. Nie dyskutując $w$ tym momencie szczegótowo nad ramami literatury politycznej określonymi przez J. Czubka, należy zwrócić uwagę na to, że pominięcie przez niego takich pism, jak panegiryki, relacje i dokumenty urzędowe jest tylko w części uzasadnione.

H. Michalak w badaniach nad drukami ulotnymi zajęła się m.in. także twórczością panegiryczną, doceniając jej propagandowe znaczenie ${ }^{13}$. Polityczne funkcje części panegiryków staropolskich potwierdzają także badania J.W. Zawiszy, który zwrócił uwagę na to, że utwór panegiryczny poświęcony osobie znaczącej w życiu 
społeczno-politycznym kraju, podkreślał słuszność postępowania adresata, agitując tym rzesze szlacheckich czytelników ${ }^{14}$.

Również w przypadku wielu relacji (nowin, doniesień, opisów itp.) można mówić o ich agitacyjnym, a nie tylko informacyjnym charakterze ${ }^{15}$.

Kolejna kwestia jaka nasuwa się w związku z definicją J. Czubka to problem funkcji dokumentów urzędowych. Otóż na podstawie badań bibliograficznych można postawić hipotezę, że ten typ pism wydawano niekiedy jako argument w dyskusji publicznej nad jakimś określonym wydarzeniem lub problemem politycznym.

Następnie grupa utworów przynoszących wiedzę o faktach i aktualnych wydarzeniach politycznych, nastawionych przy tym na popularyzację i propagowanie określonych idei, rozwiązań danych kwestii społecznych, gospodarczych, wyznaniowych to pisma publicystyczne ${ }^{16}$ i okolicznościowe. Rozróżnienie publicystyki od utworów okolicznościowych proponuje J. Nowak-Dłużewski, wskazując na to, że literatura okolicznościowa ma bardziej doraźny charakter niż publicystyka ${ }^{17}$. $Z$ kolei J.Z. Lichański uważa, że termin „publicystyka” należy zastąpić pojęciem „literatury okazjonalnej” ze względu na ulotność i okazjonalność piśmiennictwa tego typu ${ }^{18}$.

Omówione wyżej trudności terminologiczne wynikają z synkretyzmu literatury staropolskiej, ograniczającego możliwości klasyfikacyjne. Wielotematyczność, wielokodowość piśmiennictwa staropolskiego obrazują m.in. zwiąki i relacje zachodzące np. między poezją polityczna, parenetyką, traktatami polityczno-prawnymi i niekiedy dziełami historycznymi ${ }^{19}$. W efekcie publicystyka zawierała często elementy myślenia abstrakcyjnego i odwrotnie - traktaty „sensu stricto” teoretyczne nie były pozbawione treści publicystycznych.

Podobnie ścisłe związki łączą okolicznościową poezję polityczną z poezją polityczną. Według S. Nieznanowskiego należy jednak te dwa pojęcia rozróżnić, gdyż okolicznościowa poezja polityczna "ma określone wyraźnie cele, chce wpływać na kształt zdarzeń i kaptować zwolenników dla proponowanych rozwiazań", natomiast poezja polityczna cechuje się uniwersalizmem i nie jest poezją agitacyjną ${ }^{20}$.

Powyższe stwierdzenia uzasadniają tezę, że nie można zawęzić pojęcia "literatury politycznej" jedynie do tekstów perswazyjno-agitacyjnych.

Do literatury politycznej, czy raczej polityczno-prawnej należy zaliczyć także twórczość naukową (tzn. różnego rodzaju traktaty polityczno-prawne i społecznoetyczne, traktaty i rozprawy prawnicze), opartą na rozważaniach erudycyjnych i abstrakcyjnych, refleksjach teoretyczno-metodologicznych ${ }^{21}$. Piśmiennictwo tego rodzaju było pozbawione często odniesien do aktualnej rzeczywistości, zawierało jednak analizę stosunków społeczno-politycznych, zajmowało się teorią państwa i prawa, istotą władzy i mechanizmami rządzenia, urządzeniami ustrojowymi Rzeczypospolitej i ich funkcjonowaniem.

Do podanych dotąd typów piśmiennictwa polityczno-prawnego należy dodać także dzieła z zakresu historiografii, zajmujące się przecież rozważaniami nad rozwojem życia społecznego i struktur polityczno-prawnych.

Przedmiotem zainteresowania winno być także piśmiennictwo retoryczne (począwszy od traktatów naukowych z tego zakresu na zbiorach mów skończywszy), będące narzędziem kształtowania kultury politycznej szlachty. 
Komplikacje związane $z$ określeniem pojęcia literatury polityczno-prawnej potęgują się wskutek obecności podobnej tematyki w dziełach na pozór do omawianego typu piśmiennictwa nie należących, $\mathrm{np}$. w części kalendarzy czy prognostyków. W tej sytuacji interpretacja konkretnych tekstów, a więc także ich kwalifikacja wynikająca z subiektywnych przesłanek może być nieprecyzyjna.

Wydaje się zatem, że aby objąć najpełniej problematykę literatury politycznoprawnej, w trakcie analizy źródłowej należy wykorzystać treść utworów jako kryterium kwalifikacji, drugorzędnie traktując rodzaj wypowiedzi, formę wypowiedzi, rodzaj literacki czy formę druku (w przypadku publikacji).

Z tego punktu widzenia książka polityczno-prawna jest to zespół wszystkich treści polityczno-prawnych, które można wyodrębnić w danym tekście. Chodzi tutaj o treści zwiazane ze sprawami wewnętrznymi, zagranicznymi, społecznymi, ekonomicznymi, wyznaniowymi, wojskowymi, zdrowotnymi, aprowizacyjnymi itp. Istota ksiażki omawianego typu jest także jej funkcja spoleczna, polegająca na oddziaływaniu wymienionych treści na życie umysłowe i społeczne państwa.

Zgromadzony na podstawie powyższej definicji materiał badawczy należy usystematyzować. Jednym z możliwych sposobów jego kwalifikacji jest wyodrębnienie grup piśmiennictwa, tworzących ze względu na swoją treść i funkcje pewną całość. Owe grupy, typy literatury politycznej to:

- piśmiennictwo historyczne: teoria historii; historia powszechna starożytna i nowożytna; historia Rzeczypospolitej; historia Kościoła i hagiografia; biografistyka; heraldyka i genealogia.

- dzieła z zakresu teorii państwa i prawa zawierające refleksję nad Rzecząpospolitą, jej urządzeniami ustrojowymi i funkcjonowaniem owych urządzeń w praktyce:

a) traktaty polityczno-prawne i społeczno-etyczne autorów antycznych i ich nowożytne ujęcia; podręczniki wiedzy o państwie, społeczeństwie, gospodarce; dzieła pisarzy staropolskich zawierające obok refleksji natury teoretycznej także wątki publicystyczne; traktaty parenetyczne zarówno autorów krajowych, jak i obcych.

b) publicystyka staropoiska: utwory poświęcone określonym zjawiskom występującym w życiu społeczno-politycznym państwa; piśmiennictwo dotyczące stosunków państwo-Kośció-stan szlachecki oraz polemiki wyznaniowe; utwory poświęcone sytuacji gospodarczej państwa.

- piśmiennictwo informacyjno-propagandowe: utwory o charakterze okolicznościowym i relacyjno-agitacyjnym.

- piśmiennictwo z zakresu sztuki wymowy i epistolografii: dzieła o charakterze teoretycznym autorów starożytnych i nowożytnych; aforystyka polska i obca; zbiory mów i listów.

- zespół piśmiennictwa „sensu stricto” prawniczego:

a) traktaty i rozprawy prawnicze

b) opracowania z zakresu prawa publicznego, cywilnego i karnego

c) dzieła z zakresu prawa procesowego

d) piśmiennictwo poświęcone prawu miejskiemu i ziemskiemu

e) monografie instytucji państwowych, np. trybunałów

f) druki urzędowe i zbiory praw Rzeczypospolitej 
Skontruowana w ten sposób typologia literatury polityczno-prawnej ma umowny charakter i nie stanowi zamkniętej klasyfikacji.

Kolejny problem jaki chciałbym tutaj omówić to kwestia funkcji ${ }^{22}$ jakie pełniła literatura polityczno-prawna (jej poszczególne typy) w społeczności szlacheckiej.

Sposób ujęcia funkcji piśmiennictwa tego typu ma ścisły związek ze zróżnicowaniem wewnętrznym stanu szlacheckiego, na które składają się:

- status społeczno-polityczny (tzn. przynależność warstwowa)

- funkcje pełnione w systemie wladzy

- wychowanie i wykształcenie

- kompetencje czytelnicze

- grupowe $\mathrm{i}$ indywidualne preferencje czytelnicze

- ogólna orientacja w problematyce społeczno-politycznej państwa

Ponadto na.czytelnictwo miały wpływ takie czynniki, jak: możliwości szlachty w zakresie korzystania z instytucji upowszechniająch ksiażkę (oficyny drukarskie, sieć księgarska, biblioteki) oraz stopień rozwoju całości krajowego ruchu wydawniczego.

Wymienione uwarunkowania wpłynęty na ukształtowanie się dwóch podstawowych kręgów czytelników szlacheckich: elitarnego i popularnego.

Krąg elitarny tworzyły z reguły osoby posiadające wszechstronne wykształcenie zdobyte na studiach krajowych i zagranicznych, przygotowywane od najmłodszych lat do sprawowania w przyszłości wysokich urzędów państwowych, należące do grup przywódczych, dysponujące dużymi zasobami finansowymi, odznaczające się dobrą orientacją w problematyce społeczno-politycznej państwa.

Krąg popularny tworzyła natomiast ta grupa czytelników szlacheckich, której wykształcenie ograniczało się zwykle do odbycia nauki w kolegiach. Żródłem wychowania obywatelskiego były dla nich przede wszystkim sejmiki i trybunały. Grupa ta, aczkolwiek aktywna politycznie, nie obejmowała w większości przypadków wyższych urzędów państwowych.

Należy zaznaczyć, że ów podział miał charakter ponadwarstwowy (np. struktura ilościowo-tematyczna niektórych księgozbiorów magnackich świadczyłaby raczej o przynależności ich właścicieli do kręgu popularnego niż elitarnego). Główną rolę odgrywały tutaj predyspozycje intelektualne czytelnika.

Uwzględniając przytoczone wyżej uwagi, można wymienić następujące, raczej potencjalne niż rzeczywiste, funkcje ksiażki polityczno-prawnej:

- funkcja praktycystyczno-użytkowa: według K. Dmitruka literatura staropolska stanowiła „składnik społecznych praktyk wybierania władzy, sprawowania nadzoru, ksztaltowania polityki wewnętrznej i dyplomacji'²3. Było to możliwe dzięki utylitarystycznym preferencjom twórców i czytelników ówczesnej literatury polityczno-prawnej.

Użytkowy charakter literatury omawianego typu potwierdzają wspomniane powyżej badania statystyczne nad krajowym repertuarem wydawniczym w zakresie książki polityczno-prawnej, z których wynika, że istniał ścisły związek między wydarzeniami politycznymi a liczbą publikacji polityczno-prawnych. Jako przykład moga posłużyć dane za lata 1571-1590 (okres pierwszego bezkrólewia, walk wewnętrznych związanych z elekcjami Stefana Batorego i Zygmunta III, sejmu 
pacyfikacyjnego), według których literatura polityczno-prawna stanowiła aż ok. 21\% ogólnej produkcji wydawniczej tego okresu. Większość tych publikacji to naturalnie doraźna publicystyka i wydawnictwa informacyjno-propagandowe, ułatwiające szybką reakcję na wydarzenia polityczne.

Utylitarystyczny charakter preferencji czytelniczych potwierdza także struktura tematyczna produkcji wydawniczej:

- przewaga dzieł biograficznych, genealogicznych i heraldycznych orąz (zwłaszcza w XVII w.) kompilacji i podręczników historii, a także dzieł z zakresu historii współczesnej nad publikacjami poświęconymi teorii historii i ujęciami całościowymi (syntezami dziejów Rzeczypospolitej),

- przewaga piśmiennictwa „emendacyjnego" nad twórczością naukową w przypadku publikacji poświęconych teorii państwa,

- przewaga opracowań o czysto użytkowym charakterze (prawo procesowe, zbiory praw) nad dziełami poświęconymi teorii prawa.

Analiza struktury tematycznej księgozbiorów szlacheckich kręgu elitarnego wskazuje na pewne prawidłowości. Otóż w zależności od indywidualnych zainteresowań właściciela biblioteki jej zbiory służyly jako warsztat twórczy pisarzy politycznych $^{24}$, jako księgozbiory podręczne urzędników państwowych ${ }^{25}$, bądź jako narzędzie pomocne $\mathrm{w}$ bieżącej działalności męża stanu ${ }^{26}$. W ostatnim przypadku dobór lektury nie ograniczał się jedynie do piśmiennictwa o aktualnej tematyce, związanej z określonymi problemami społeczno-politycznymi państwa ale obejmował także dzieła o charakterze uniwersainym, wykraczającym poza doraźność. Np. w księgozbiorze Stanisława Bieniewskiego, z którym właściciel podróżował na sejm 1659 r., obok dzieł bezpośrednio związanych z kozaczyzną i Kościołem grecko-katolickim - a więc problemami, którymi się aktualnie zajmował - znalazły się także traktaty: polityczno-prawne, traktaty prawnicze, traktaty z zakresu retoryki, a także piśmiennictwo historyczne (dzieje starożytne, nowożytna historia Europy, dzieje Rzeczypospolitej) ${ }^{27}$. Równie znamienna jest obecność w księgozbiorach magnackich dzieł, które można traktować jako podręczniki wiedzy o zewnętrznych oznakach i symbolice władzy - wypełniały one zapewne także określoną funkcję ideologiczną.

Księgozbiory popularnego kręgu czytelników były natomiast przystosowane raczej do potrzeb tych odbiorców szlacheckich, których sposób myślenia o państwie miał praktyczny, doraźny charakter.

- funkcja integrująca: można ją rozpatrywać w wielu płaszczyznach. Najszerzej realizowała się poprzez integrację całej szlacheckiej publiczności czytającej w zakresie literatury polityczno-prawnej. W tym przypadku istotą integracji był wspólny udział w życiu spoleczno-politycznym kraju i w sprawowaniu władzy, który wyrażał się m.in. w tworzeniu i recepcji książki polityczno-prawnej.

Inne płaszczyzny integracji, jakie można wyróżnić, to m.in. omówiony wyżej utylitarny charakter literatury staropolskiej, określone wartości ideologiczne, interesy warstwowe, programy polityczne, interpretacja i ocena wydarzeń politycznych.

Kolejną płaszczyzną integracji było istnienie kanonu literatury polityczno-prawnej aprobowanego przez ogół szlachecki, o czym świadczy zbieżność struktury tematycznej krajowej oferty wydawniczej i księgozbiorów szlacheckich. 
Równocześnie należy zwrócić uwagę na to, że księgozbiory szlacheckie, choć identyczne pod względem typologii zgromadzonego piśmiennictwa polityczno-prawnego, różniły się znacznie pod względem jakościowym (chodzi o merytoryczną zawartość działów), jak i ilościowym. Biblioteki stanowiły więc odbicie różnic zachodzących między poszczególnymi jednostkami i grupami stanu szlacheckiego.

Mając na uwadze powyższe stwierdzenie, można wysnuć wniosek o dezintegrującej funkcji książki polityczno-prawnej, realizującej się w indywidualnym procesie odbioru dzieła literackiego i wpisanej $w$ tekst dzieła $w$ przypadku piśmiennictwa perswazyjno-agitacyjnego, np. publicystyka określonego obozu politycznego miała na celu dezintegrację stronnictw reprezentujących odmienne poglądy w zakresie polityki zewnętrznej czy wewnętrznej państwa.

- funkcja informacyjno-propagandowa: funkcję tę wypełniały następujące typy piśmiennictwa: część traktatów polityczno-prawnych (zwłaszcza twórczość „emendacyjna"), publicystyka, a przede wszystkim zespół druków informacyjnopropagandowych (okolicznościowa poezja polityczna, vota senatorskie i inne; listy, responsy; nowiny, relacje itp.).

Cechą charakterystyczną publikacji tego typu była ich jednostronność. Przeznaczone były mianowicie dla określonego adresata-szlacheckiej opinii publicznej - natomiast nadawcy wywodzili się z elit przywódczych, reprezentując zwykle środowiska magnackie lub dworskie.

Równocześnie badania nad siedemnastowiecznymi księgozbiorami szlacheckimi dowodzą, że biblioteki kręgu popularnego zawierały znacznie więcej publikacji omawianego typu, niż biblioteki kręgu elitarnego. Ten stan rzeczy może uzasadniać hipoteze, że piśmiennictwo omawianego rodzaju było przeznaczone i miało odbiorców przede wszystkim wśród tych warstw szlacheckich, które w XVII w. staly się przedmiotem a nie podmiotem politycznym.

$Z$ kolei jednak należy zaznaczyć, że trudno jest na podstawie niepełnych inwentarzy księgozbiorów ustalić rzeczywistą ilość piśmiennictwa informacyjnopropagandowego, zważywszy, że ulegało ono często zagubieniu lub zaczytaniu, bądź w ogóle nie umieszczano go w spisach książek.

- funkcja ideologiczna: jednym z istotnych problemów badań nad staropolską książką polityczno-prawną jest próba odpowiedzi na pytanie: w jakim stopniu ten typ literatury przyczyniał się do utrwalenia lub zmiany określonych elementów ideologii szlacheckiej?

Według danych bibliograficznych podstawowe wartości ideowe, takie jak: szlacheckość, równość, wolność, osiadłość, patriotyzm, katolicyzm znalazły swe odbicie we wszystkich wyróżnionych typach literatury polityczno-prawnej, publikowanej na terenie Rzeczypospolitej. Owe wartości stanowily punkt wyjścia do wszelkich rozważań nad problematyką państwa, w którym szlachta nominalnie odgrywała decydującą rolę.

Ze względu na stopień akceptacji ideologii szlacheckiej i modelowych rozwiązań ustrojowych państwa, w staropolskiej literaturze polityczno-prawnej można wyróżnić trzy główne nurty twórczości:

- apologetyczny: odnosił się bezkrytycznie zarówno do ideologii szlacheckiej, ideowych założeń funkcjonowania państwa, jak i do ich praktycznej realizacji, 
- moralizujący: aczkolwiek w pełni akceptował urządzenia ustrojowe Rzeczypospolitej ( $z$ naczelną zasadą, „złotej wolności" włącznie) to jednak odnosił się w sposób krytyczny do otaczającej rzeczywistości. Sprzeczność teorii z praktyką thumaczono tutaj zwykle zanikiem w świadomości szlachty konieczności istnienia równowagi między prawami jednostki, czy warstwy, a jej obowiązkami wobec państwa lub demoralizacją stanu szlacheckiego. Nurt ów dażył do socjalizacji szlachty, stworzenia z niej społeczeństwa obywatelskiego, świadomego swoich praw i obowiąków, na którym spoczywa odpowiedzialność za stan Rzeczypospolitej,

- reformistyczny: opowiadal się za uszczupleniem prerogatyw szlachty przy równoczesnym zwiększeniu zakresu władzy królewskiej lub magnackiej.

Wymienione kierunki polskiej myśli politycznej łączyły: przywiązanie do katolicyzmu jako religii panującej państwa i generalna aprobata systemu politycznego Rzeczypospolitej, opartego na symbiozie instytucji republikańskich, monarchicznych i oligarchicznych, tzn. senatu określanego jako stan pośredni „inter majestatem et libertatem".

W świetle analizy repertuaru wydawniczego krajowych oficyn drukarskich wydaje się, że największą aprobatą wśród publiczności czytającej cieszył się nurt moralizatorski polskiej literatury polityczno-prawnej.

W księgozbiorach szlacheckich obu kręgów - elitarnego i popularnego znalazły się dzieła nawiązujące do wszystkich wymienionych nurtów piśmiennictwa polityczno-prawnego, reprezentowane przez najwybitniejszych pisarzy polskich XVI i XVII wieku. Przy czym księgozbiory kręgu elitarnego, bogatsze o kanon europejskiej literatury polityczno-prawnej, gromadziły dzieła o bardzo zróżnicowanej proweniencji ideologicznej. Znalazły się w nich prace reprezentujące zarówno arystotelesowsko-tomistyczną doktrynę w zakresie teorii państwa, jak i ideologię absolutystyczna, publikacje nawiązujące do teorii umowy społecznej i dzieła propagujące ideę teokratycznej budowy państwa. W omawianych księgozbiorach nie zabrakło także pism monarchomachów i utopistów szesnastowiecznych.

Trudno ocenić na ile podobna wszechstronność w doborze lektury wynikała ze skłonności komparatystycznych czytelników czy ich otwartości na różne idee, teorie polityczno-prawne, zważywszy, że epoka, w której omawiane księgozbiory powstały to okres kultury erudycyjnej, retorycznej, którą cechowało dażenie do rejestracji wszystkich źródeł z danej dziedziny.

W tej sytuacji ocena specjalnych preferencji ideologicznych poszczególnych właścicieli bibliotek szlacheckich sprawia duże trudności i wymaga przeprowadzenia badań o znacznie większym stopniu szczegółowości, wykraczających poza zakres przyjęty dla niniejszego opracowania.

- funkcja poznawcza: staropolska literatura szczególnie podkreślała wagę wyksztalcenia w zakresie wiedzy o państwie i prawie oraz znajomości podstawowych metod sprawowania władzy i działalności politycznej, jako niezbędnego warunku w wypelnianiu przez szlachtę powinności obywatelskich.

Jako jedno z narzędzi poznania w tej dziedzinie wymieniano książkę polityczno-prawną. Ten postulat nie został w praktyce urzeczywistniony, gdyż jak można stwierdzić na podstawie analizy produkcji wydawniczej krajowych oficyn drukarskich, wobec niedostatecznej podaży piśmiennictwa o charakterze teoretycznym, 
wartości poznawcze krajowej literatury polityczno-prawnej w zakresie wiedzy uniwersalnej, teoretycznej były ograniczone (powszechnie większą wage przywiązywano raczej do praktyki politycznej i pism z nią związanych, jako źródel wiedzy o państwie i społeczeństwie). Analiza struktury tematycznej księgozbiorów popularnego kręgu czyłelników szlacheckich wskazuje na to, że repertuar wydawniczy był adekwatny do ich potrzeb. Natomiast czytelnicy należący do kręgu elitarnego zaspokajali swoje potrzeby poznawcze głównie za pomocą importowanej literatury europejskiej.

- funkcja wychowawcza: realizowała się poprzez oddziaływanie na społeczność szlachecką za pomocą propagowania określonych wzorców i cech osobowych, zachowań i działań społeczno-politycznych, postaw obywatelskich i wartości ideowych - godnych naśladowania.

Ksiażka polityczno-prawna służyła równocześnie jako czynnik kształtowania i utrwalania tożsamości szlachty, wskazując na jej odrębność i uprzywilejowaną pozycję w społeczeństwie, decydującą rolę, jaką winna odgrywać w państwie. Określone w ten sposób cele wychowawcze spelniały przede wszystkim: historiografia staropolska, piśmiennictwo parenetyczne oraz część utworów okolicznościowych, np. panegiryki. Dzieła z tego zakresu można znaleźć w większości księgozbiorów szlacheckich. Należy przy tym zwrócić uwagę na obecność w bibliotekach magnackich stosunkowo dużej liczby traktatów parenetycznych, poświęconych wzorcom „dobrego księcia, władcy chrześciańskiego”, co wskazywałoby na preferencje czytelnicze i „klasowe" tej warstwy szlacheckiej.

- funkcja prestiżowa: w okresie staropolskim jednym z zewnętrznych wyznaczników prestiżu społecznego, obok okazałych rezydencji, posiadania własnego dworu, była także bogata biblioteka. Świadczyła ona nie tylko o zamożności zbieracza ale także była dowodem jego edukacji, ogłady i kultury.

Mąż stanu, działacz polityczny uzyskiwał autorytet i posłuch w obrębie tych środowisk szlacheckich, w których działał m.in. dzięki swojej erudycji i oczytaniu.

Do prestiżowego znaczenia wykształcenia w zakresie wiedzy polityczno-prawnej szczególną wagę przywiązywała magnateria.

Podsumowując, można stwierdzić, że staropolska literatura polityczna - przy całym bogactwie jej zawartości tematycznej - miała przede wszystkim charakter użytkowy. Była tworzona z myślą o najszerszych masach szlacheckich, odpowiadała na społeczne preferencje czytelnicze stanu. Nie zaspokajała natomiast w całości potrzeb lekturowych elitarnego kręgu czytelników szlacheckich, który realizował swoje potrzeby poznawcze poprzez lektury pisarzy europejskich.

\section{Przypisy}

1 J. Stryczek-Puchalski, Rola i funkcje książki polityczno-prawnej w środowisku szlachty koronnej w latach 1587-1732, praca magisterska napisana w Instytucie Bibliotekoznawstwa i Informacji Naukowej Uniwersytetu Warszawskiego w 1989 r. Maszynopis, IBIN, sygn. M. 1307.

${ }^{2} \mathrm{Na}$ temat podobnych granic epoki XVII w. w Polsce wypowiadali się m.in.: J. Maciszewski, Szlachta poiska i jej państwo, Warszawa 1986, s. 152, C. Hernas, Literatura Baroku, Warszawa 1987, s. 20-21.

${ }^{3}$ Przebadano następujące inwentarze księgozbiorów szlacheckich, dzieląc je ze względu na ich strukturę ilościowo-tematyczną na dwie grupy: 
- biblioteki elitarnego kręgu czytelników, należące do takich właścicieli, jak: marszałek nadworny koronny kukasz Opaliński, inwentarz jego księgozbioru zostal opublikowany przez K. Schuster, Biblioteka Łukasza Opalińskiego marszalka nadwornego koronnego (1612-1662), Wroclaw 1971, s. 180-257; dzialacz i pisarz ariański Stanisław Lubieniecki (1623-1675), inwentarz jego biblioteki opublikował J. Tazbir, Księgozbiór Stanisława Lubienieckiego, "Rocznik Biblioteki Narodowej" 1968, s. 197-223; magnat Aleksander Michał Lubomirski (1614-1677), inwentarz jego księgozbioru opublikował J. Długosz, Księgozbiór Aleksandra Michała Lubomirskiego w świetle inwentarza z 1678 roku, "Ze Skarbca Kultury" 1972, s. 197-223; sekretarz królewski Hieronim Pinocci, nobilitowany na sejmie 1662 r., inwentarz opublikowany przez K. Targosz, H. Pinocci. Studium z dziejów kultury naukowej w Polsce w XVII wieku, Wroclaw 1967; Jan Sobieski (1629-1696), inwentarz jego biblioteki opublikował J.T. Lubomirski, Katalog książek biblioteki najjaśniejszego, najpotężniejszego króla polskiego z Bożej Łaski, Jana III Sobieskiego, szczęśliwie panującego, spisany w 1689 r., Kraków 1879, a omówiony w pracy I. Komasary, Jan III Sobieski - miłośnik ksiąg, Wroclaw 1982; polityk, dyplomata Stanisław Kazimierz Bieniewski (zm. 1676), którego księgozbiór omówiła W. Jabłońska; magnat Jan Adam Stadnicki (zm. 1713) i koniuszy wielki koronny Jerzy Dzieduszycki -W. Jabłońska, Inwentarze i katalogi biblioteczne w zbiorach rękopiśmiennych Biblioteki Zakładu im. Ossolińskich, "Ze Skarbca Kultury" 1969, s. 111-153.

- biblioteki popularnego kręgu czytelników, należące do takich właścicieli, jak: Stanisław Sapiński, szlachcic wielkopolski, inwentarz jego biblioteki opublikował M. Koza, Z księgozbiorów szlacheckich w Wielkopolsce XVII w. "Roczniki Historyczne” 1934, s. 179-180; Maciej Grabski, inwentarz jego ksiegozbioru opublikowala P. Buchwald-Pelcowa, Inwentarz biblioteki Macieja Grabskiego (z zagadnień czytelnictwa w drugiej połowie XVII w.), „Rocznik Biblioteki Narodowej" 1966, s. 318-337; ponadto wykorzystano tutaj informacje na temat księgozbiorów: szlachcianki Justyny Lorkowskiej, Szkice $z$ dziejów dawnej Bydgoszczy XVI-XVIII w., Bydgoszcz 1975, s. 128-131; kasztelana nakielskiego Jana Grudzińskiego, M. Koza, op. cit., s. 281; łowczego gostyrískiego Krzysztofa Dobińskiego, J. Partyka, Rękopiśmienne księgi szlacheckie - źródła i inspiracje, [W:] Staropolska kultura rękopisu, Warszawa 1990, s. 83-84; szlachty krakowskiej, inwentarze z lat trzydziestych XVIII w. omówione przez H. Bogdanow, Literatura społeczno-polityczna jako wyraz zainteresowań szlachty krakowskiej w XVII wieku, „Studia o Książce" 1973, s. 345-374.

${ }^{4}$ Do rekonstrukcji repertuaru wydawniczego w zakresie literatury polityczno-prawnej posłużyły:

- material statystyczny opublikowany przez M. Czarnowską, llościowy rozwój polskiego ruchu wydawniczego 1501-1965, Warszawa 1967.

- spisy bibliograficzne: K. Estreicher, Bibliografia polska XV-XVIII wieku, t. 12-34, Kraków 1939 i uzupełnienia do niej; J. Nowak-Dłużewski, Bibliografia staropolskiej okolicznościowej poezji politycznej XVI-XVIII wieku, Warszawa 1964; K. Zawadzki, Gazety ulotne polskie i Polski dotyczące XVI-XVII wieku, t. 1-2, Wroctaw 1977-1984; Dramat staropolski: Od poczatków do powstania sceny narodowej. Bibliografia, Warszawa 1965; Bibliografia literatury polskiej .Nowy Korbut”, t. 2-3, Warszawa 1964-1965.

${ }^{5}$ B. Bieńkowska, Inwentarze księgozbiorów prywatnych jako źródła do badań nad dziejami czytelnictwa, "Studia o Książcen 1989, s. 69-71.

${ }^{6}$ J. Siemieński, Polska kultura polityczna wieku XVI, [W:] Kultura staropolska, Kraków 1932, s. 132.

${ }^{7}$ H. Olszewski, Ustrój polityczny Rzeczypospolitej, W:] Polska XVII wieku, Warszawa 1969, s. 69.

8 J. Leszczyński, Siedemnastowieczne sejmiki a kultura polityczna szlachty, [W:] Dzieje kultury politycznej w Polsce, Warszawa 1977, s. 54.

${ }^{9}$ W. Czapliński, Rola sejmów XVII wieku w kształtowaniu się kultury politycznej w Polsce, [W:] Dzieje kultury politycznej w Polsce, s. 47.

10 J. Chrościcki, Sztuka i polityka, funkcje propagandowe sztuki w epoce Wazów 1587-1668, Warszawa 1983, s. 23.

${ }^{11}$ Ok. $28 \%$ analfabetów wśród magnaterii, ok. $40 \%$ wśród szlachty średnię i ok. $42 \%$ wśród szlachty drobnej, według obliczeń K. Dmitruka, Sytuacje komunikacyjne w kulturze literackiej dawnej Polski, [W:] Z dziejów życia literackiego w Polsce XVI i XVII wieku, Wrocław 1980, s. 34.

12 J. Czubek, Pisma polityczne z czasów rokoszu Zebrzydowskiego, t. 1, Kraków 1918, s. IV.

${ }^{13} \mathrm{H}$. Michalak, Druk ulotny jako narzędzie integracji politycznej paŕstwa, ${ }_{n}$ Odrodzenie i Reformacja w Polsce" 1983, s. 69. 
14 J.W. Zawisza, Panegiryczny druk okolicznościowy epoki Stanislawowskiej, Wroctaw 1984, s. 130-131.

${ }^{15}$ U. Augustyniak, Informacja i propaganda w Polsce za Zygmunta III. Warszawa 1981, s. 94-99.

${ }^{16}$ Definicję publicystyki staropolskiej sformułował E. Kotarski w pracy: Dziedzictwo i tradycja. Szkice o literaturze staropolskiej, Gdańsk 1990, s. 126.

17 J. Nowak-Dłużewski, Okolicznościowa poezja polityczna w Polsce, t. 2-5, Warszawa 1966-1971.

${ }^{18}$ J.Z. Lichański, W kręgu literatury staropolskiej, „Przegląd Humanistyczny” 1975, s. 126.

${ }^{19}$ E. Kotarski, op. cit., s. 119; H. Dziechcińska, Parenetyka - jej tradycje i znaczenie w literaturze, [W:] Problemy literatury staropolskiej. Seria pierwsza, t. 1, Wroclaw 1972, s. 298.

20 S. Nieznanowski, Barokowa poezja polityczna. Propozycje badawcze, $W:]$ Problemy literatury staropolskiej. Seria trzecia, t. 1, Wrockaw 1972, s. 298.

21 E. Kotarski, op. cit, s. 124-125.

${ }^{22}$ Definicję funkcji sformułował $P$. Sztompka w pracy: O tak zwanych wyjaśnieniach funkcjonalnych w socjologii i antropologii spolecznej, .Studia Socjologiczne” 1968, s. 225.

${ }^{23}$ K. Dmitruk, op. cit, s. 34

24 Jako przykład mogą tutaj służyć księgozbiory Ł. Opalińskiego, S. Lubienieckiego i H. Pinocciego.

${ }^{25}$ Szczególnie charakterystyczny pod tym względem jest księgozbiór $\mathrm{H}$. Pinocciego.

${ }^{26}$ M.in. księgozbiory A.M. Lubomirskiego, J. Sobieskiego i S.K. Bieniewskiego.

${ }^{27}$ W. Jabłoŕska, op. cit. 